\title{
PIONEERING EMBRYOLOGICAL RESEARCH AT THE OLD ANATOMICAL THEATRE OF THE UNIVERSITY OF TARTU
}

\author{
MaIe Toomsalu \\ Department of Anatomy, University of Tartu, Tartu, Estonia
}

\begin{abstract}
The reopening of the University of Tartu (1802) fell into the period when the society's needs for science and educated people were increasing rapidly. Universities became the most important research institutions, and their lecturers were not merely teachers but professional scientists. German higher education fostered ties with the most significant research centres of that time's world. The current article views the pioneering embryological research done at the Old Anatomical Theatre, which has made the names of these scientists known in the whole world and brought honour and fame to the University of Tartu.

The article describes the embryological studies by Karl Friedrich Burdach, Martin Heinrich Rathke, Carl Bogislaus Reichert, Ernst Reissner, Emil Woldermar Rosenberg, Carl Wilhelm von Kupffer, Arthur Boettcher (Böttcher), Karl Dietrich Barfurth, Maximilian Gustav Christian Carl Braun, August Antonius Rauber and Nikolai Czermak.
\end{abstract}

Keywords: embryology; embryological development; human; mammals; birds; fish; reptiles; brain; nervous system; skeleton

\section{INTRODUCTION}

When speaking about embryological research at the University of Tartu, one would first recall the name of Karl Ernst von Baer. Karl Ernst von Baer really is the best-known embryologist originating from Estonia; he is known to the world primarily as the discoverer of the ovum of mammals. Although K. E. von Baer graduated from the University of Tartu, defended his doctoral dissertation 
De morbis inter esthonos endemicis (1814) and spent his old age in Tartu, being at the head of the Estonian Naturalists' Society, he has never been a professor at the University of Tartu. K. E. von Baer's research was based on Chr. H. Pander's (was a medical student in Tartu from 1812-1814) discoveries concerning germinal leaves and primordial folds. Baer, however, approached the topical problem of epigenesis from a totally new aspect. He made his great discovery when working at the University of Königsberg. In 1827 he published his epoch-making work De ovi mammalium et hominis genesi, which described the ovum discovered by him and its microstructure. Baer also studied the gills of mammals' embryos and the umbilical cord that connects the foetus to the mother organism.

Embryological research at the University of Tartu, however, started much earlier, when K. E. von Baer was still a medical student here.

\section{EMBRYOLOGICAL RESEARCH}

Karl Friedrich Burdach came to Tartu from Leipzig in 1811 to the post of the professor of anatomy, physiology and forensic medicine. He had a doctoral degree in both medicine and philosophy. In Tartu, he lectured on physiology, embryology, medical propaedeutics and taught a course called Geschichte des Lebens (history of life).

Burdach's interpretation of the evolutionary idea of progressive development and unity of nature in the spirit of Schelling's natural philosophy allows us

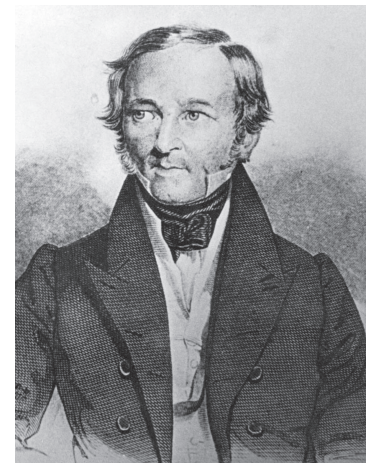
to consider him an evolutionistic biologist of the preDarwin period. Influenced by the factual research material, which did not fit Schelling's scheme, Burdach abandoned the metaphysics of natural philosophy; this became apparent both in his public presentations and in publications. A special place in Burdach's legacy belongs to his ground-breaking works on the anatomy and physiology of the nervous system. His studies in this area served as a basis for the monumental treatises Vom Bau und Leben des Gehirns (2 volumes, 1819-1822) and Umrisse einer Physiologie des Nervensystems (1844). Vladimir Alexandrovich Betz (Russian anatomist, 1834-1894), one of the creators of the cytoarchitectonics of the cerebral cortex has emphasised, "The real and solid basis for modern anatomy of the brain was laid in the works of Burdach (professor of the University of Tartu)" [3: 15]. 
K. Fr. Burdach himself has reminisced, "I set myself two main tasks, which seemed to me up to date and particularly suitable for my mental character: development of theories on the brain and procreation".

"I divided the brain precisely into parts; while doing this I tried to register individual peculiarities and relate them to the collected materials on living conditions. I studied the changes that various chemical reagents produced in the substance of the brain, as namely these facilitate the study of its texture, and I even observed different kinds of mould, the number of which depends on the impact of objective circumstances; I also began to study the brains of embryos and certain animals. This is how I prepared for the treatment of evolution; I dissected embryos, studied earlier observations, particularly those by Harvey (English physician and anatomist, 1578-1657, discoverer of blood circulation) and Autenrieth (Johann Heinrich Ferdinand Autenrieth, German medical scientist, professor of Tübingen University, published works on physiology). My students included Pander (Christian Heinrich Pander, 1794-1865, Russian naturalist of Baltic German origin, one of the founders of micropaleontology, worked at the Medical Faculty of the University of Tartu from 1812-1814, academician of St. Petersburg Academy of Sciences, 1823) and von Baer (Karl Ernst von Baer, 1792-1876, naturalist, founder of modern embryology, studied at the University of Tartu from 1810-1814), both of whom have, with their excellent studies, created the foundation for their theory in its present form" [6: 94].

Burdach was one of the pioneers of applying the ontophylogenetic method of studying the brain. By the method of splitting, he established the structure of the white and grey matter of the brain, the brain's connections with the cerebellum; he described in detail the ontogenesis of the internal capsule and the corpus striatum. He proposed the method of dividing the brain into lobes that has found acceptance in science. He established the ontogenetic and morphological differences between sulci and gyri. Burdach's special merit was the differentiation of the projection, commissural and associative systems of the brain; a wedge-shaped funiculus in the spinal cord bears his name (fasciculus Burdachi), nucleus cuneatus is also known as Burdach's nucleus, and some other elements of the central nervous system are also known by his name [5: $195,1390,1444]$.

The anatomico-physiological orientation of Burdach's works exerted special influence on the neurological studies of the Czech physiologist Johannes Evangelista Purkinjé (1787-1869); the German naturalist, professor of anatomy and physiology at the Universities of Bonn and Berlin Peter Johannes Müller 
(1801-1858); the German neurologist Robert Remack (1815-1865); and the physiologist Georg Friedrich Karl Heinrich Bidder (1810-1894), who studied medicine at the University of Tartu from 1828-1834, was professor of anatomy at the University of Tartu from 1836-1842 and physiology and pathology from 1843-1869, from 1858-1865 also Rector of the University of Tartu, corresponding member (1857) and honorary member (1884) of St. Petersburg Academy of Sciences [7: 370-373; 17:29, 18:34].

Martin Heinrich Rathke was elected head of the chair of physiology, pathology and semeiotics of the University of Tartu on 17 September 1828 on Burdach's recommendation. Rathke was 36 years old then and author of more than 50 research papers. M. H. Rathke's doctoral dissertation (1818) dealt with salamander's genital organs and their development ( $D e$ salamandrum corporibus adiposis, overies et oviductibus, eorumque evolutione). In the monograph published in 1825, Beiträge zur Geschichte der Thierwelt,

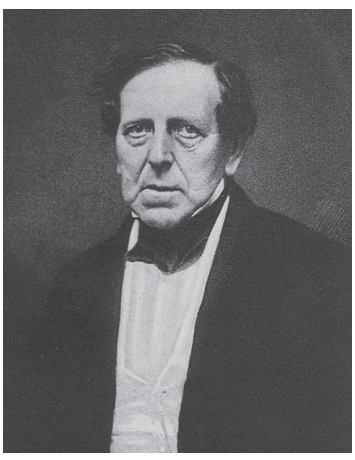
he explained the development of the urogenital system from fish to birds. In birds, he discovered mesonephros that he called the Wolffian body. The section concerning mammals, however, remained incomplete. In 1825 Rathke published two articles - "Gills in mammals" and "Gills in birds". By discovering gill slits in mammals and birds, Rathke made a fundamental discovery that demonstrated the unity of embryonal development in all classes of vertebrates. In 1828, Rathke discovered gill slits in humans too, which was immediately thereafter confirmed by Baer.

In 1829, Rathke published a monograph on the embryonal development of the crayfish - Untersuchungen ueber die Bildung und Entwickelung des Flusskrebses. Incidentally, Rathke found that the yolk in crayfish as well as in Branchipus and Lepidurus is not positioned ventrally, like in vertebrates, but dorsally. Consequently, the development of an invertebrate animal's embryo is quite different from vertebrates. Thus, Rathke had refuted Saint-Hilaire's famous thesis (1822) about the comparability of crustaceans and vertebrates. On 27 June 1831, his work received the golden medal of the Paris Academy of Sciences.

In the crayfish monograph, Rathke also demonstrated that the crayfish's blastoderm differentiates into two germinal layers and they, in their turn, into final derivatives. The germinal leaves of vertebrates had been discovered 
earlier (in 1817) by Christian Heinrich Pander. Rathke made the generalization that the genesis and differentiation of germinal leaves is a principal process of embryonal development in all animals.

In the first half of 1833, Rathke, with his students Kappger and Kutorga (later a physiologist at St. Petersburg University), travelled in the Crimea and in the surroundings of Odessa. The result of the expedition was a major work on fauna (1837, Zur Morphologie. Reisebemerkungen aus Taurion) with the description of 9 new species of fish and 15 species of crustaceans. Its second part (1837) described the development of sea anemones and some crustaceans and scorpions and made some additional generalizations on the embryology of crustaceans.

The fact that most houses in Tartu swarmed with cockroaches enabled Rathke to study the development of this classical zootomical object (1832). He discovered that the cockroach does not develop a yolk sac, but yolk is enclosed into the developing intestine.

In Tartu, Rathke was primarily engaged in improving, revising and generalizing his earlier studies. He published a book on the gill apparatus and hyoid of vertebrates Anatomisch-philosophische Untersuchungen ueber Kiemenapparat und das Zungenbein der Wirbelthiere (1832). An essential merit of the book is that it clarified the evolutional interaction between the development of gill curves, operculum and some bones of the skull, including the inner ear bones. The second book consists of two parts: papers on the development of humans and animals (1832-1833) Abhandlungen zur Bildung und Entwicklungsgeschichte des Menschen und der Thiere. A large part of the book discusses the embryology of the urogenital system. A substantial part of knowledge on the development of the urogenital tract via pro-, meso- and metanephros is based on Rathke's studies.

During his Tartu period, Rathke started a series of studies on comparative anatomy and embryology of the cardiovascular system. He was especially interested in the development of the heart from an initial simple tube, and the reduction and reconstruction processes of embryonal vasculature. Rathke made a significant addition to the understanding of the morphology of organogenesis, treating organogenesis as budding or bulging from a simple initial funicular or tubular primordium.

In 1836, Rathke took over K. E. von Baer's post in Königsberg and continued research begun in Tartu on the interaction between the genesis of hypophysis and pharynx, describing the formation known today as Rathke's pouch. A monograph on the evolution of reptiles (1839) and generalization of data 
concerning the embryology of the skull (1839) followed. In 1841, he made additions to the study of the lancelet. The papers of 1848 and 1853 explained the interaction between the spine, ribs, forelimbs and shell of reptiles. Rathke's last book, Entwicklungsgeschichte der Wirbeltiere, was published in 1861 by Kölliker [9: 3-8].

Carl Bogislaus Reichert came to the University of Tartu in 1843 from Berlin. He was invited to Tartu on the recommendation of the well-known professor of physiology at the University of Tartu, F. Bidder, and his own friend A. von Humboldt. He attracted attention in the academic world by his dissertation completed in Berlin in 1936, De arcubus sic dictis bronchialibus. For his paper Ueber die Entwicklung des befruchteten Säugetiereies, he received an academic award and golden medal.

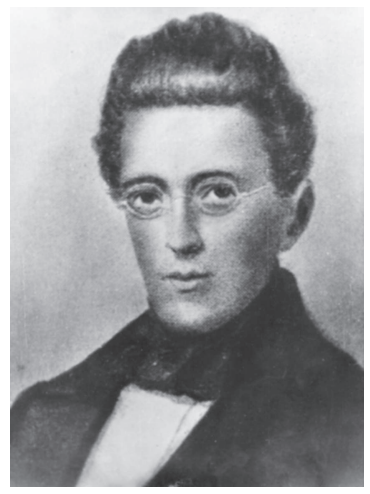

At the University of Tartu, Reichert lectured, besides anatomy, also on embryology, doing it on the basis of his own works. Reichert studied the gill arches of vertebrates, their metamorphoses in birds and mammals and the embryogenesis of mammals. In Tartu, he wrote the work Bemerkungen zur vergleichenden Naturforschung in allgemeinen und vergleichenden Beobachtungen über das Bindgewebe und die verwandten Gebilde (1845) that made him famous. In this histogenetic study as well as in his other works Reichert refuted the contemporary theory of the free formation of cells in liquid cytoblastema and, having studied the development of organisms, stated that all cells in the body derive from existing cells. This theory, later widely spread by R. Virchow, claimed: "Omnis cellula a cellula". He also studied the continuity of the connective tissue, proving the connection between cartilaginous, osseous, mucous and other kinds of connective tissue, and proved that all histological processes derive from cells and not from some kind of liquid (blastema) as suggested by Schleiden-Schwann's theory. As a result of his embryological works, we know Reichert's cartilage and Reichert's socket.

In Tartu, Reichert joined F. Bidder in his study of ganglions and helped a number of researchers in their work, for example, Reissner's Ueber die Bildung des inneren Ohres. In his memoirs, Bidder has written that Reichert was an extremely talented and hard-working scientist. His lectures of embryology attracted some of the largest audiences these days [15: 234]. 
Reichert studied the processes of segmentation of the ovum, the formation of embryonal leaves, the development of the connective tissue, auditory ossicles and the skull. Reichert was also the first to make an important discovery on the crystallization of haemoglobin. This made it possible to get albuminous preparations in a pure form. The discovery had great significance for the study of oxygen transfer mechanisms in respiratory processes. In $1850 \mathrm{C}$. B. Reichert was elected a corresponding member of St. Petersburg Academy of Sciences.

In 1853, he took the post of professor of physiology at the University of Breslau (now Wrocław, Poland) [17: 48-50; 18: 60].

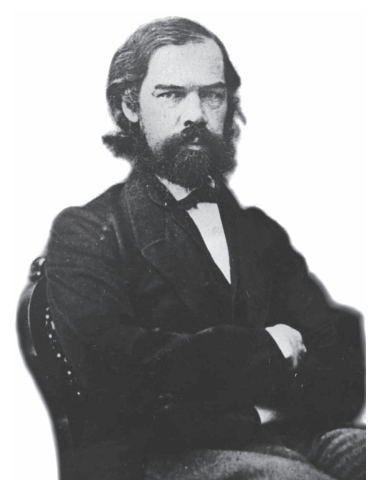

Ernst Reissner studied at the Faculty of Medicine of the University in Tartu and in 1851, under the supervision of Reichert, defended his doctoral thesis De auris internae formatione (On the Development of the Middle Ear). When C. B. Reichert was invited to Breslau, Reissner became his successor at the Chair of Anatomy. In 1852, as a result of development of light microscopy, the anatomist A. Corti, who had been educated in Vienna, discovered nervus coclearis (Corti's organ) in the labyrinth of the inner ear. At the same time, embryological and comparative anatomical research of the internal ear led A. Reissner to the discovery of the vestibular membrane that bears the name membrane vestibularis Reissneri. This thin and tender skin in ductus cochlearis separates two perilymphatic and one endolymphatic cavity. Reissner's further studies led him to the discovery of the socalled Reissner's channel (canalis Reissneri) in the cochlea. Reissner's articles that attracted attention in international scientific circles include "Beitrag zur Kenntnis der Haare des Menschen und der Säugetiere" (Breslau, 1854), "Zur Kenntnis der Schnecke im Gehörorganer der Säugetiere und des Menschen” (Müller’s Archiv für Anatomie, Physiologie und Wissenschaftliche Medicin, 1854), "Ueber die Schwimmblase und den Gehörapparat einiger Siluroiden" (Müller's Archiv, 1859), "Beitrag zur Kenntnis vom Baue des Rückenmarkes von Petromyzon fluviatilis" (Müller's Archiv, 1860), "Der Bau des centralen Nervensystems der ungeschwäntzten Batrachier” (Dorpat, 1864) [17: 51-52; 18: 62].

Emil Woldermar Rosenberg is a graduate of the University of Tartu. His doctoral dissertation Untersuchungen des Canalis cochlearis der Säugethiere 


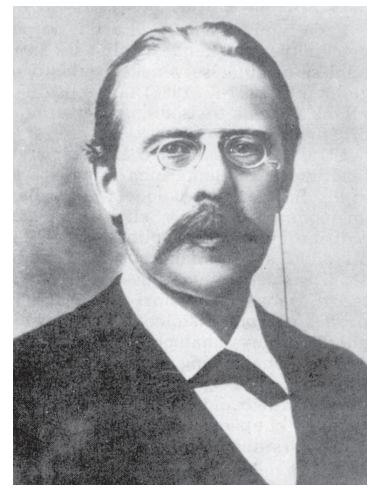

dealt with the embryonal development of the cochlea in mammals. When, in 1876 , the new chair of embryology, histology and comparative anatomy was founded at the University of Tartu, E. Rosenberg was offered the post of full professor there. In 1877, he became full professor of the new chair. He gained fame for his work in studying the phylo- and ontogenetic development of the human spinal column. He was primarily interested in the phylo- and ontogenetic development of the cervical region of the spinal column and the skull. Relying on numerous embryological and comparative anatomical studies, E. Rosenberg attempted to prove that variations in human vertebrae on the upper and lower edge of the thorax, which consist in the existence or lack of ribs, are atavistic. This theory caused serious arguments with other scientists [16: 33-35].

Carl Wilhelm von Kupffer is a graduate of the University of Tartu. He is considered to be the founder of comparative embryology. In 1857, C. Kupffer and F. Bidder issued a joint publication Studies on the Structure of the Cord and its Formative Elements (Untersuchungen über die Textur des Rückenmarkes und die Entwickelung seiner Formelemente, Leipzig 1857). Its embryological section was written by C. Kupffer who, for the first time, described the development of the spinal cord in different embryonal periods. During

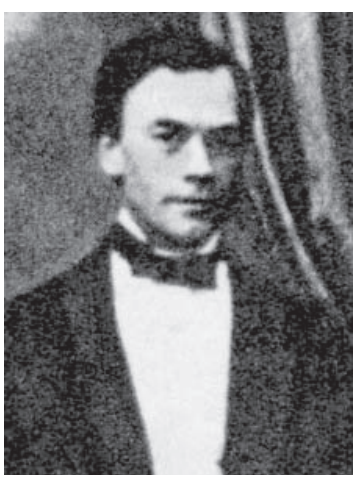
his Tartu period, C. Kupffer also won recognition with his articles Untersuchungen über die Entwickelung des Harn- und Geschlectssystems, Ueber das Faltenblatt der Embryonen bei Chironomus. Kuppfer continued embryological research, first at the University of Kiel, then in Königsberg (1875-1880) and Munich [4:21-25].

Arthur Boettcher (Böttcher) was a graduate of the University of Tartu. In 1856, he defended in Tartu his dissertation Observationes microscopiae de ratione, qua nervus cochleae mammalian terminator. As professor at the Chair of Pathology and Pathological Anatomy at the University of Tartu, his main object of research was the development and structure of mammals' internal ear (labyrinth) [1: 147]. In 1869, he published Ueber Entwicklung und Bau des Gehörlabyrinthes nach Untersuchungen an Säugethieren. The paper won great 


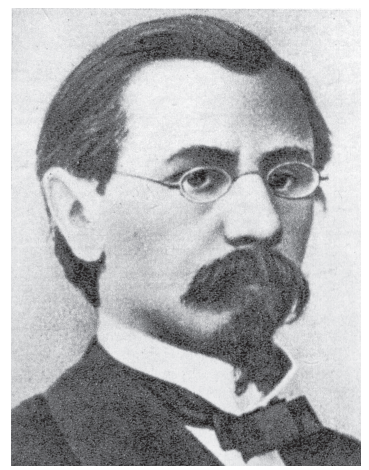

recognition, and, in 1870, Boettcher received the Baer Prize for it from St. Petersburg Academy of Sciences. In 1874, the University of Tartu awarded him the Heimbürger Prize. A. Boettcher was elected honorary member of the Paris Society of Otology and Laryngology. For decades, the structures discovered by him were designated by his name (Boettcher's cells, Boettcher-Cotugno space, Boettcher's ganglion) [17: 91-95; 18: 108-112].

Karl Dietrich Barfurth, who had obtained the degree of Doctor of Philosophy in 1874, defended a doctoral dissertation in medicine, Zur Entwickelung der Milchdrüse, in 1882. In 1889, he was appointed to the post of full professor at the Chair of Anatomy, Embryology and Histology at the University of Tartu. In Tartu, Barfurth lectured on comparative anatomy of invertebrates, general and special histology and development history of humans and vertebrates. He supervised practical training in histology and embryology and supervised histological and embryological research. He supported the experimental trend in research. He mostly studied connections between cells, regeneration and development mechanisms of tissues. A few examples: Versuche über die Regeneration des Auges und Linse beim Hühnerembryo (Anat. Anz. Ergh., 1902, 21: 185-195), Die Erscheinung der Regeneration bei Wirbelembryonen (Jena, G. Fischer, 1903).

\section{By the time Maximilian Gustav Christian Carl}

Braun came to the University of Tartu, he had obtained a doctoral degree in medicine for his dissertation Ueber die histologischen Vorgänge bei der Häutung von Astacus fluvialis and in zoology for Lacerta Lilfordi und Lacerta muralis, zugleich ein Beitrag zur Reptilienfauna der kleinen Inseln des Mittelmeeres. On 5 October 1879, M. Braun was invited to the University of Tartu to take the post of prosector of embryology, histology and comparative anatomy. The object

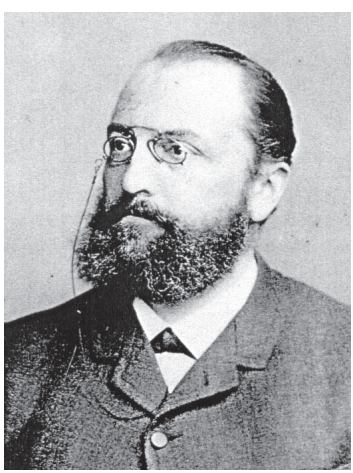
of his embryological research was development of the tail in mammals' embryos [4: 280-285]. 


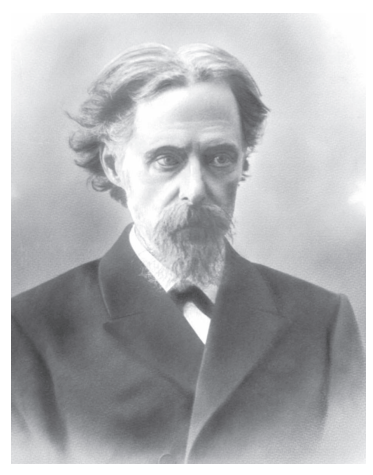

August Rauber was invited to the University of Tartu in 1886. In Tartu he devoted himself to the study of the embryology of vertebrates and to the anatomy of the nervous system and skeleton. He conducted embryological research on hens, fish and amphibians. A. Rauber never confined himself to the description of findings but drew essential generalizations and conclusions. For example, while studying the hen's embryo, he found that two-layered embryonic shield is a modified gastrula. He demonstrated that primary streak and sulcus are a connated blastopore. With contemporary equipment, A. Rauber was not able to exhaustively explain the importance of the primary streak. Nonetheless, he reached the conclusion that the genesis of embryonic layers and histogenesis cannot be understood without solving the problem of the primary streak and the sulcus. The concept of the neurula (the neural plate - primordium of the nervous system - formed in the back of the embryo after the gastrular stadium) also originates from A. Rauber.

A. Rauber studied the influence of mechanical and chemical factors, temperature, air pressure and gravitation on the developmental processes. He was the first to study the development of embryonic cyst of the rabbit using serial layers. He made an important discovery, demonstrating the existence of a special covering layer of the embryonic cyst; the importance of this layer of cells as a primordium of trophoblast became clear only after A. Rauber's death. The trophoblast layer, i.e., the layer of blastocyst's wall, separating the embryoblast from the external environment in solid-hoofed animals and lemurs, is now called Rauber's layer [11: 129-172].

Nikolai Czermak was appointed professor of embryology, histology and comparative anatomy at the University of Tartu. He had started embryological research under the famous Philipp Owsjannikov (a graduate of the University of Tartu) in St. Petersburg. From 1896-1902 N. Czermak studied the germ cells of fish and amphibians and, in 1901, discovered and described chondriosomes or mitochondria. The same discovery was made by M. and W. H. Lewis in 1914 [2: 51;17:156-157; 18: 186].

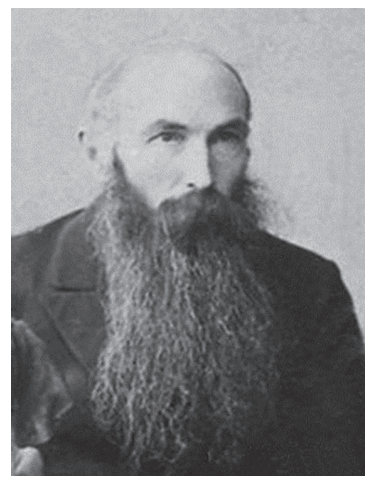




\section{CONCLUSION}

This golden era of embryological research in the Old Anatomical Theatre put the scientists of the University of Tartu on the map of the world, and, until today, every medical scientist in the world knows and uses such eponyms as fasciculus Burdachi, Burdach's nucleus, Rathke's pouch, Reichert's cartilage and Reichert's socket, Reissner's channel (canalis Reissneri), Reissner's membrane, Kupffer's cells, Boettcher's cells, Boettcher-Cotugno space, Boettcher's ganglion and Rauber's layer.

\section{REFERENCES}

1. Anniko M. (1985). Arthur Boettcher, Karl Bogislaus Reichert and Ernst Reissner. 19th Century Pioneers in Inner Ear Research at the Tartu University in Estonia. Eesti Teadusliku Seltsi Rootsis aastaraamat. Annales Societatis Litterarum Estonicae in Svecia, Stockholm, 145-149.

2. Arend Ü., Kalnin V. (1977). O razvitii gistology i embriology na meditsinskom fakultete Tartuskogo universiteta. Tartu Ülikooli ajaloo küsimusi, IX, 43-61 (in Russian).

3. Bets V.A. (1950). Anatomicheskie i gistologiecheskie issledovaniya. Moskva, 15 (in Russian).

4. Biograficheski slovar professorov i prepodavatelei imp. Yuryevskogo, byvsh. Derptskogo universiteta (1802-1902) (1903). Pod. Red. G. V. Levitskogo, Yuryev. Vol. I-II (in Russian).

5. Dorlands Illustrated Medical Dictionary (1988). W. B. Saunders Company, 195, 1390, 1444.

6. Issakov S. (1986). Mälestusi Tartu ülikoolist (17.-19. sajand). Tallinn.

7. Kalnin V., Lepp E. (1986). Karl Friedrich Burdach. Nõuk Eesti Tervish, 5, 379-373.

8. Käbin I. (1986). Die medizinische Forschung und Lehre an der Universität Dorpat/Tartu 1802-1940: Ergebnisse und Bedeutung für die Entwicklung der Medizin. Lüneburg: Nordostdt. Kulturwerk.

9. Käer-Kingisepp E. (1985). Lehekülgi Tartu Ülikooli arstiteaduskonna õppetööst XIX sajandi algusaastail. Nõuk Eesti Tervish, 28, 118-122.

10. Käer-Kingisepp E., Põldvere K. (1975). Martin Heinrich Rathke. TÜ ajaloo küsimusi, III. Tartu, 3-8.

11. Lubosch W. (1924). August Rauber. Sein Leben und seine Werke. Anatomischer Anzeiger, 58, 6/7, 129-172.

12. Raikov B.E. (1969). Germanskie biology-evolutsionisty do Darwina. L. Oken, K.F. Burdach, M.H. Rathke. Leningrad (in Russian). 
13. Rathke M. (1837). Zur Morphologie. Reisebemerkungen aus Taurion. Riga u. Leipzig.

14. Rooks G., Kogerman E.P. (1962). Iz zhizni i deyatelnosti A. Raubera. Archiv anatomy, gistology i embriology, 1, 110-116 (in Russian).

15. Tartu ülikooli ajalugu (1982). 234.

16. Tehver J., Paaver K. (1963). Aleksander ja Emil Rosenbergid - väljapaistvad Tartu morfoloogid. Eesti Loodus, 1, 33-35.

17. Toomsalu M. (2002). Vana Anatoomikumi professorid. Tartu.

18. Toomsalu M. (2006). Professors of the Old Anatomical Theatre of University of Tartu.

\section{Address for correspondence:}

Maie Toomsalu

Department of Anatomy

University of Tartu

Ravila Street 19, 51014 Tartu, Estonia

E-mail: maie.toomsalu@ut.ee 